\title{
Editor's Message: 25 years of Hydrogeology Journal
}

\author{
Clifford I. Voss ${ }^{1}$ • A. C. (Carla) Skinner ${ }^{2}$
}

Received: 18 September 2017 / Accepted: 20 September 2017 / Published online: 18 October 2017

(C) US Government (outside the USA) 2017

Keywords Hydrogeology Journal · History of hydrogeology

Hydrogeology Journal, the official journal of the International Association of Hydrogeologists (IAH, www.iah.org), has experienced remarkable growth in its first 25 years. Hydrogeology Journal (HJ) has become a first-class international venue for authors and readers worldwide with publications related to hydrogeology, subsurface processes, groundwater resources and groundwater management, and human interactions with hydrogeologic systems.

\section{Early history}

The beginnings of what is now $H J$ can be dated to 1989 when the International Geological Congress (IGC) was held in Washington, DC. IAH then followed a practice of not holding its own congress in the 4-year cycle of the IGC, but the groundwater sessions at the congress were a de-facto IAH congress (see Struckmeier et al. (2016) regarding the history of IAH). The quality of the sessions was high but the IGC offered no vehicle for the publication of full manuscripts. IAH was already publishing a series of monographs (the 'blue

C.I. Voss is the executive editor of Hydrogeology Journal; A.C. (Carla) Skinner was the IAH secretary general 1989-2004 and the IAH executive manager 2004-2008

Clifford I. Voss

cvoss@usgs.gov

1 US Geological Survey, 345 Middlefield Rd, MS 496, Menlo Park, CA 94025, USA

2 Bertie Road, Kenilworth CV8 1JP, UK books') through the German publishing house Heise (Verlag Heinz Heise), but that series did not cover collections of conference proceedings. Skinner (a scientist working in environmental regulation in the UK and the incoming IAH secretary general), felt there was a need in a pre-digital age to give the general IAH membership access to the technical outputs from conferences held by their organization. Heise publishers were open to starting a parallel book series, which became entitled Selected Papers (the 'green books') and the 1989 IGC provided a rich source of material to make the first volume of the new series a success. These ideas were supported by the incoming secretary of the US National Chapter of IAH, Pat Leahy, a US Geological Survey (USGS) scientist. Eugene Simpson (a professor at University of Arizona; see Neuman and Campana 1998) with assistance from John Sharp (a professor at University of Texas) agreed to edit the volume. This was done swiftly and successfully and the first Selected Papers volume was published in 1990.

Prior to this, there had been discussions from time to time on the need for IAH to have its own journal. Publishers sensing a gap in the market had talked to both IAH and to senior IAH members as individuals. There was a feeling in IAH that both its standing as a professional body and the delivery of its mission would be enhanced if IAH were the sponsor of a journal of repute, but up to 1990, no proposal had gelled. However, Gene Simpson, who had enjoyed the experience of producing the IGC volume and had become respected by the Heise publishers, made it known that he would be willing to act as founding editor of an IAH journal. This offer from a well-respected groundwater scientist was taken up with enthusiasm by IAH and a deal to begin the journal was concluded at a meeting in the Sherlock Holmes Hotel in Baker Street, London, in summer 1991 between Simpson, Skinner, and Christian Heise (head of the Heise company), and this led to the pilot issue, which was humorously denoted as 'Volume 0 ', 
being published in 1992 — see Struckmeier et al. (2016) for more information on how the Heise connection occurred.

The initially preferred title for the new journal was Hydrogeology but BRGM (France) and French members of IAH did not favor this choice because of perceived conflict with the occasional BRGM journal publication, Hydrogéologie. IAH also wanted a title that was in some way distinctive from that of the major existing groundwater journals, Journal of Hydrology and Groundwater. In a wish to emphasize the new journal's relevance to practice in the profession, IAH settled on the title Applied Hydrogeology.

The journal had a shaky start. People liked what they saw but there was not enough content and the new journal did not appear in a timely manner. IAH needed a bigger team to source material and assist coordination between editor and publisher and this became even more evident when Gene Simpson began to experience health issues and eventually had to give up the editorship. Temporary editors filled the gap until Clifford Voss, an active USGS scientist, and William Wilson, a USGS retired scientist, came on board in 1994 as the editor and technical editor, respectively. They were recruited by John Moore (also a USGS scientist and then current IAH president) on behalf of IAH, and USGS has been funding some of Cliff's time for the executive editor work ever since. Cliff urged that the title be changed to Hydrogeology Journal (starting in 1995), so that the journal would be inclusive of all types of hydrogeology and groundwater science, including theory and practice, and including all types of hydrogeologists as authors and readers. The goal was to make Hydrogeology Journal the primary world forum for hydrogeological research and practice.

Manuscripts were submitted to the journal by postal mail and reviewed on paper (yes, on physical paper!). The two editors also managed the peer-review process for submitted manuscripts. However, to fill issues that appeared four times per year in the first years, articles had to be solicited by the editors and were contributed mainly by authors dedicated to making the new journal a success. By around 1996, the new journal was beginning to be noticed in the international hydrological community and was receiving more unsolicited submittals. In these early years, layout, copy editing and final article proofs were done in Bill Wilson's house, on his own computer and printer with some support from his wife, Kathie, and then sent to Heise for printing.

In 1996, IAH and Heise reviewed progress with the journal, and came to a joint and amicable agreement that it would be in the interests of both parties if the publishing contract was allowed to lapse and that IAH should seek a new publishing partner. The IAH journal did not fit well with the main Heise publishing business (focused on German telephone catalogs, a magazine for computer technology, and on IT information exchange). IAH needed a partner more closely integrated within the geoscience community to increase the journal's exposure and reputation. Some academic publishing houses had already noted the emergence of Applied Hydrogeology/ Hydrogeology Journal and made informal overtures to IAH. Early in 1997, formal discussions were opened with two of those companies, Springer Verlag and John Wiley \& Sons, Inc. Both made competitive offers. The decision went in favor of Springer and, beginning in 1998, Springer, under the leadership of Wolfgang Engel in their Heidelberg office, published the journal. The initial contract was to produce six 100-page $H J$ issues per year. Thus, at this time, IAH is not only recognizing the 25th anniversary of $H J$ but also a very successful and much-appreciated 20-year partnership with Springer (recently expanded to Springer Nature; Springer Nature 2017).

\section{Later history}

Actual production of $H J$ became much easier for the editors once Springer took over in 1998, as Springer supplied professional support staff (Susanne Schemann, née Schweickert) and copy/layout editors. $H J$ 's editorial staff has evolved significantly since then. Bill Wilson retired from his editorship and two more USGS retirees came on board as managing editors, Robert Schneider (in 2001) and Perry Olcott (in 2002), as the peer-review load grew with increasing journal size.

In 2001, IAH also increased support to $H J$ by providing an editorial office manager (Christine Watson, formerly Skinner's assistant at the Environment Agency in the UK), who took care of daily interactions with all authors, editors, associate editors, reviewers and translators. This worked very well, but after a few years of increasing submittals, the manuscript load became impractical for the existing editors. Starting in 2005, when Schneider and Olcott ended their terms, and with the support of IAH and Springer, Cliff initiated a new review system consisting of four editors who were university professors. This system is still in place. To date, the editors have been: Philippe Renard (University of Neuchâtel, Switzerland), Bridget Scanlon (University of Texas, USA), Maria-Theresia Schafmeister (University of Greifswald, Germany), Craig Simmons (Flinders University, Australia), Shemin Ge (University of Colorado, USA), Jiu Jimmy Jiao (University of Hong Kong, China), and Vincent Post (Flinders University, now at BGR-Hannover, Germany). Current editors are Martin Appold (University of Missouri, USA), JeanMichel Lemieux (Université Laval, Canada), Elizabeth Screaton (University of Florida, USA), and Maria-Theresia, who has been an editor since 2005 .

At the same time the new four-editor system began in 2005, IAH also appointed an additional $H J$ staff member, the technical editorial advisor (TEA), who would interact with authors after technical acceptance of their manuscript and make it conform to standard $H J$ formats. More importantly, the TEA would help authors who were non-native-English speakers to 
improve their scientific expression, making all published articles appear in professional English language. Providing this service was part of fulfilling the IAH goal of making $H J$ accessible as a publication outlet to authors all over the world. Sue Duncan (who was a groundwater scientist with the Environment Agency in the UK) has been in this position, supporting $H J$ authors, ever since.

In 2006, Susanne Schemann, who had been the primary Springer support person from HJ's beginning at Springer (a position that had ended a couple years earlier) took over as $H J$ 's editorial office manager when Christine ended her term. Susanne has been on the $H J$ team ever since. At Springer, Wolfgang Engel was $H J$ 's main contact until his passing in 2006, then Christian Witschel managed HJ for Springer through 2014, at which time Carlo Schneider took over.

At first, $H J$ provided title and abstract translations in French and Spanish, later adding Portuguese and Chinese. Several abstract translation managers have been responsible for providing translations with their teams over the years. There have been a few hundred associate editors over the years, who select reviewers and provide advice to the editors on the publishability of each submittal. The journal could not exist without the wonderful voluntary support for both translation and review provided by these dedicated professionals.

\section{$H J$ growth and recognition}

Indeed, $H J$ has grown in all ways in its 25 years. Most years included a theme issue (now called special issue) that contains only invited articles on a particular subject. These are highly cited issues initially organized by the executive editor (Cliff) who selects the subject and then finds volunteer guest editors who manage actual issue organization, invitations to authors, and reviews of the submittals. Additionally, $H J$ has been regularly publishing article groups (now called topical collections), consisting of several articles focused on a particular topic, usually suggested and organized by a volunteer group leader. The full list of special issues and topical collections can be found on the IAH website.

The article types that were established by the editors evolved over the years. Currently, $H J$ publishes Papers (subjects with results that are generic and transferable to other studies, including valuable technical review papers), Reports (articles that describe a particular area, usually like a case study, or application of known techniques), Technical Notes (articles that describe new methods and approaches) and Profiles (articles that summarize the contributions of particular eminent hydrogeologists). Comment and Reply exchanges allow discussion of published $H J$ articles. $H J$ also provides the Essay article type, which can express the opinions of authors, rather than requiring a typical scientific presentation that undergoes normal technical review.
Once well established as an international journal in the early 2000 s, $H J$ grew in size. $H J$ 's yearly submittals increased from about 200 in 2003 to about 550 in 2017, while yearly accepted articles increased from 66 to about 200 over the same period. Printed pages increased from about 300 in 1995, to 900 in 2005, 1,900 in 2013, and 2,200 in 2016. Yearly issues increased from four to six in 1999 and then to eight in 2006. In total, as of the current issue at the end of 2017, there have been $26 \mathrm{HJ}$ volumes with about 160 issues, containing over 2,400 articles.

$H J$ has experienced increasing recognition both as a highquality scientific journal and a practically useful journal. The impact factor increased steadily from about 0.5 in 2000 (the first year the impact factor was assigned to $H J$ ) to 2.109 for 2016. The 5-year impact factor is 2.484 for 2016 and the h5 index is 28 for 2016. These measures indicate how often $H J$ articles are cited in total by other scientific articles in journals - an academic determination of the quality of a journal's articles. Two more-practical measures that are of interest to IAH (recall the original name for this journal, Applied Hydrogeology) are the number of full-text downloads of $H J$ articles and the usage factor (the median value of the number of downloads for all articles published online during the same time period). There were more than 220,000 downloads in 2016 alone, and the usage factor for 2015/2016 is 283, an impressive set of recognition measures.

Because $H J$ presents a natural balance of theoretical and practical hydrogeology, it welcomes and publishes case-study type articles. As a result, it might be expected that HJ's academic impact factor can never become very high. Many casestudy articles are of a practical nature that mostly local or similar interests elsewhere will find of value. Many of these more-practical $H J$ readers are professional hydrologists and water managers who use the information in their work; they are not academics who publish papers in journals and cite such references. The practical part of the $H J$-reader audience will download papers and use the published information without citing these articles in another journal article that they create. Thus, $H J$ 's impact factor will likely not become very high, in contrast with $H J$ 's download statistics, which could indicate the high practical value of many of $H J$ 's published articles.

Clear steady progress has occurred toward the goal that the late Gene Simpson had set for himself and for IAH, to produce a journal of repute that would improve the delivery of the IAH mandate and the standing of the organization. No doubt Gene, as a former USGS scientist himself, would take pleasure from the fact that Cliff, his long-standing successor, is himself a USGS scientist who has received the support of USGS in this work.

\section{Subscription and publishing models}

Springer Nature distributes $H J$ mostly as part of a larger earthscience package of journals to library and institutional 
subscribers. Subscriptions are also provided to the over 4,000 IAH members. Benefits of publishing via $H J$ and Springer have evolved over the years to include: free color figures, no firm page limits on articles (which can be as long as the editors and author agree that they need to be), no page charges for authors, and the possibility to publish translations of each article's title and abstract in over 40 languages. In recent years, open access publication (at no cost to the reader) has evolved into a necessity for many authors due to changes in regulations requiring open access to results of government-funded projects in many countries. In the past, Springer provided free downloads of $H J$ articles to subscribers and IAH members, and at-cost downloads for non-subscribers. This system remains in place, but a new option called Open Choice is provided by Springer, in which the author can pay to publish the article and then it becomes freely available to everyone upon publication. Authors are beginning to use this publication model more for $H J$, especially as Springer has provided a benefit to IAH members, who pay a lower costs for Open Choice (about half) than non-members of IAH. However, even the half-cost may deter some authors, perhaps affecting more authors in developing countries than elsewhere, from publishing open access articles, and IAH will need some consideration of this question.

Some years ago, IAH began offering its members an online-only subscription to $H J$, with a lower yearly IAH membership fee than for those who prefer paper copies of bound issues. This is, in effect, an economic incentive to IAH members, resulting in some members selecting online-only simply to lower their membership fee. Together with the greater cost of printing and shipping paper journals to subscribers, this combination may force $H J$ to become online-only (no more paper journal) in the next years, to the disappointment of those who prefer to physically page through each issue, rather than hunt online for specific articles and topics (as people now do on the Internet). Loss of the paper journal may also decrease access in world regions where internet services are not yet well established and readers rely on the paper issues. IAH will also need to consider this question. An online-only journal may imply other changes in the publishing model, including continuous online publication of articles without assignment to particular issues of $H J$.

\section{Future developments and issues}

There is a continually increasing number of manuscripts submitted to $H J$ partly as a result of more participants in hydrogeology studies, and partly due to more participation by authors from new countries on the international hydrology scene such as China. There is also pressure from Springer to further increase the number of articles published in $H J$, as their company income depends on this count each year. How should the IAH and $H J$ deal with these pressures? Intentionally increasing initial rejection rates can help because immediate rejection upon submittal, due to an out-of-journal-scope or poor-quality assessment by an editor, directly reduces the workload of $H J$ staff, editors, associate editors, reviewers and translators. Rejection rates have naturally become higher over the years, perhaps in conflict with the implicit IAH goal to publish articles from developing country authors. However, even with higher rejection rates, a continually growing journal implies a need for more editors, more staff time, and thereby more IAH and Springer funding for $H J$ operation. One approach to increase published articles with least impact on the $H J$ editors at least may be to increase the publication of special issues that have volunteer guest editors who manage much of the extra work.

Another situation to resolve is $H J$ 's difficulty in recruiting the three volunteer technical reviewers needed for each manuscript. $H J$ uses about 1,000 reviewers each year for manuscripts that pass through the full review process. How can so many volunteers be found? This is a problem not only for $H J$, but also for all other similar scientific journals that rely on peer review for guaranteeing the quality of published articles. The publication business has expanded greatly with the advent of many new (perhaps low-quality) online-only journals, keeping many of the review-capable people so busy that they either do not agree to take on a review request, or never finish it once they agree.

We'll see how these developments and concerns have evolved and have been hopefully resolved by the next big $H J$ anniversary in 5 or 10 years from now... In the meantime, $H J$ is an extraordinary achievement of which IAH is proud.

Comments and thoughts from $H J$ authors and readers are always welcome!

\section{References}

Neuman SP, Campana ME (1998) Editorial: Tribute to Eugene S. Simpson. Hydrogeol J 6:1-2

Springer Nature (2017) Hydrogeology Journal. http://www.springer.com/ hydrogeologyjournal. Accessed September 2017

Struckmeier W, Howard K, Chilton J (2016) The International Association of Hydrogeologists (IAH): reflecting on 60 years of contributions to groundwater science and water management. Hydrogeol J 24:1069-1086. https://doi.org/10.1007/s10040-0161434-7 